http://dx.doi.org/10.1590/0370-44672014690092

\author{
Marcelo Henrique Farias de Medeiros \\ Professor Doutor \\ Universidade Federal do Paraná - UFPR \\ Departamento de Construção Civil \\ Curitiba - Paraná - Brasil \\ medeiros.ufpr@gmail.com
}

\section{Eduardo Pereira \\ Professor Doutor \\ Universidade Estadual de Ponta Grossa - UFPG \\ Departamento de Engenharia Civil \\ Ponta Grossa - Paraná - Brasil \\ engenheiroeduardopereira@gmail.com}

\section{Valdecir Angelo Quarcioni \\ Pesquisador II \\ Instituto de Pesquisas Tecnológicas do Estado de São Paulo \\ Laboratório de Materiais de Construção Civil \\ São Paulo - São Paulo - Brasil \\ quarciva@ipt.br}

\author{
Paulo Roberto do Lago Helene \\ Professor Titular \\ Universidade de São Paulo - USP \\ Escola Politécnica \\ Departamento de Construção Civil \\ São Paulo - São Paulo - Brasil \\ paulo.helene@concretophd.com.br
}

\section{Introduction}

When a structure has its construction completed, the layman thinks its materialization costs have ceased. However, under the action of usage, it will need to undergo maintenance to ensure the proper performance of its functions.

Under standard conditions, the reinforcing steel is physically protected by a barrier consisting of the concrete cover. This barrier limits the ingress of substances that can start the corrosion process and limits the access of water and oxygen. Having a good quality concrete, with high density and high electrical resistivity, it will be less susceptible to ionic

Civil Engineering

\title{
Surface treatment systems for concrete in marine environment: Effect of concrete cover thickness
}

\begin{abstract}
There are some ways to extend the service life of a reinforced concrete structure. This paper focuses on the extension of the service life by treating the surface of reinforced concrete, specifically on the effect of the concrete cover thickness on the surface treatment system efficacy. Thus, chloride migration tests were performed and diffusion chloride coefficients were calculated. The service life of each case (treated or non-treated concrete) was estimated using these data and Fick's second law of diffusion. Results indicated that the thicker the concrete cover is, the greater the efficacy of the concrete surface treatment system will be. The dissemination of this information is important, since it is almost intuitive to think that the effect of a surface treatment system depends only on itself and this study shows the opposite.
\end{abstract}

Keywords: chloride, concrete, durability, surface protection, service life.

movements, and therefore, the corrosion process will slow down.

However, it is not only the concrete cover variable that interferes in the depassivation time and kinetics of reinforcement corrosion. Some studies such as Guimarães et al. (2003) and Meira et al. (2007) show the influence of the distance of the structure in relation to the sea, showing that the attack intensity is severely reduced when distance from the coastline increases. Medeiros et al. (2013) studied an in situ reinforced concrete structure showing that the higher the concrete is, the lower the chloride con- tamination degree will be and showed the influence of the wetting and drying cycles which increase the speed of chloride contamination. These are important aspects, indicating that service-life models and building standards should consider these effects. However, many research works are needed to make possible the improvement and production of more realistic and accurate service life models.

In this context, surface treatment is an alternative to increase the service life of reinforced concrete structures. The aim of this work is to study the increase in service life caused by the protection of concrete 
surfaces exposed to marine environments. More specifically, to study the influence of

\section{Experimental program}

\subsection{Concrete substrate}

The concrete of the substrate was produced with a Brazilian Portland cement designated CPII E-32, which is equivalent to ASTM C 595 (Slag-modified Portland cement). This cement has blast furnace slag addition and is one of the most widely used cements in the state of São Paulo, Brazil.

\subsection{Surface Protection Systems}

Five protection systems were used, all are commercial products specified for surface treatment of reinforced concrete structures exposed to chloride ions environments. Table 1 presents a sum-

\begin{tabular}{|c|c|c|c|}
\hline Group & Treatment system & Identification & $\begin{array}{l}\text { Description } \\
\text { manufature }\end{array}$ \\
\hline Pore liners & Single & Water repellent & $\begin{array}{l}\text { Silane/siloxane - } \\
\text { dispersed in water }\end{array}$ \\
\hline Pore blocker & Single & Sodium silicate & $\begin{array}{l}\text { Product based on } \\
\text { sodium silicate } \\
\text { marketed for } \\
\text { protection and } \\
\text { waterproofing of } \\
\text { concrete }\end{array}$ \\
\hline \multirow{2}{*}{ Coating } & Single & Acrylic & $\begin{array}{l}\text { Varnish Acrylic- } \\
\text { dispersed in solvent }\end{array}$ \\
\hline & Single & Polyurethane & $\begin{array}{l}\text { Varnish polyurethane } \\
\text { (Bicomponent) }\end{array}$ \\
\hline Double system & Double & $\begin{array}{l}\text { Water repellent + } \\
\text { Acrylic }\end{array}$ & $\begin{array}{c}\text { (silane/siloxane - } \\
\text { dispersed in water) + } \\
\text { (Varnish acrylic - } \\
\text { dispersed in } \\
\text { base solvent) }\end{array}$ \\
\hline
\end{tabular}

The consumption of material indicated by the manufacturers was respected

in the implementation of all protection systems used in this work.

\subsection{Chloride migration test (non-steady state condition)}

The migration tests were conducted similarly to the ASTM C 1202/12 procedure, but with some modifications. The differences are the voltage applied, of $30 \mathrm{~V}$ (instead of $60 \mathrm{~V}$ ), the 30-hour testing time (instead of 6 hours) and the measurement of the chloride penetration depth (instead of total charge passed).

After curing time, each cylindrical concrete cover thickness on the potential protective systems of surface treatments products. The choice of these protection systems aims to compare some products of the three groups of surface protection systems: Pore liners (make the concrete mary of the studied surface protection specimen $(100 \mathrm{~mm}$ in diameter and 200 $\mathrm{mm}$ in length) was cut into two $50-\mathrm{mm}$ wide slices from the central nucleus of the original specimen. Although most researchers adopt the use of a single central slice for the migration test, in this study they were drawn from two central slices based on a previous work (Medeiros et al. 2009 and Medeiros et al. 2012a), which for concrete in an environment contaminated with chloride ions.
RH environment during 91 days, used to obtain a high degree of hydration. This was chosen because migration tests involve the exposure of the surfaces to moisture and this could cause additional hydration in untreated concrete but not in concrete with treated surface.

water-repellent), pore blockers (react with some of the soluble concrete constituents and form insoluble products) and coatings (form continuous film on the concrete surface).
Table 1

Description of the systems included in the study. statistically proved that it is totally possible to use up to three 50 -mm thick slices in a migration test without compromising the results. Six slices were used to represent each case studied.

After the drying procedure ( 7 days in laboratory environment $-25{ }^{\circ} \mathrm{C}$ and R.U. $70 \pm 4 \%$ ), the protection materials were applied on only one circular surface 
of the specimens. Afterwards, the specimens were vacuum-saturated during 24 hours. This procedure consisted in conditioning specimens in vacuum desiccators and applying a vacuum pressure of 1 $\mathrm{mmHg}(133 \mathrm{MPa})$ during 3 hours. Then, the desiccator was filled with de-aerated water until all specimens were immersed, and the vacuum pressure was maintained for one additional hour. Afterwards, the vacuum pump was turned off, and the specimens were maintained immersed during 20 hours.

Seven days after the application of the surface treatment, the 50-mm-thick specimen was placed between two acrylic cells, each cell with $280 \mathrm{~cm}^{3}$ of solution

Where: $\mathrm{R}=$ gas constant $(8.31 \mathrm{~J} / \mathrm{molK})$; $\mathrm{T}=$ temperature $(298 \mathrm{~K}) ; \mathrm{z}=$ is the ion valence (for chloride $=-1$ ); $F=$ Faraday constant (96.5 J / Vmol); $\mathrm{E}=$ electric field $(-600 \mathrm{~V} / \mathrm{m}) ; \mathrm{x}_{\mathrm{d}}=$ chloride penetration depth $(\mathrm{m}) ; \mathrm{t}=$ test time $(\mathrm{s})$, $\mathrm{a}$ and $\mathrm{b}=$ constants. When $\mathrm{E}=-600 \mathrm{~V} / \mathrm{m}$ and

\section{Results and discussion}

Table 2 presents chloride diffusion coefficient data measured with the proce-

Table 2

Chloride diffusion coefficient measured in each case.

Using the chloride diffusion coefficient values determined by the method proposed by Luping and Nilsson (1992) and applying the

Where: $\mathrm{C}_{\mathrm{Cl}}=$ chloride content at depth $\mathrm{e}_{\mathrm{Cl}}$, at time $\mathrm{t}(\%) ; \mathrm{C}_{\mathrm{s}}=$ chloride content in the surface of the volume. One cell was filled with $0.3 \mathrm{~N}$ $\mathrm{NaOH}$ aqueous solution and the other with $3.0 \% \mathrm{NaCl}$ aqueous solution. The cells were connected to a $30 \mathrm{~V}$ power source during 30 hours, in which the electrode immersed in $\mathrm{NaOH}$ aqueous solution was the anode and the electrode immersed in $3.0 \% \mathrm{NaCl}$ aqueous solution was the cathode.

After 30 hours of the migration test, the concrete slices were fractured in the direction of the chloride flux and an aqueous solution of $\mathrm{AgNO}_{3} 0.1 \mathrm{M}$ was sprayed on the recently fractured surface. This procedure causes the formation of two well-defined regions (one white, one brown). The white region is formed due

$$
D=\frac{R T}{z F E} \frac{\mathrm{x}_{\mathrm{d}}-\mathrm{ax} \mathrm{x}_{\mathrm{d}}^{\mathrm{b}}}{t}
$$

$\mathrm{T}=298 \mathrm{~K}, \mathrm{a}=1.061$ and $\mathrm{b}=0.589$.

This method is based on chloride migration in non-steady-state conditions (according to Fick's law). According to Luping and Nilsson (1992), with this procedure, the test time is a few hours for conventional concrete and about 2 days for high to $\mathrm{AgCl}$ precipitation, and, therefore, represents the region containing chlorides. The brown region corresponds to the region free of chlorides. Importantly, the white region corresponds to the site with free chloride (water soluble chloride), and the measurement refers to the front of free chloride penetration excluding the combined chloride (Meck and Sirivivatnanon 2003).

Luping and Nilsson (1992) established a mathematical model to determine the chloride diffusion coefficient in non-steady-state conditions. The chloride diffusion coefficient calculation according to these authors is performed using Equation 1. dure formerly described for the reference concrete (without treatment) and for concrete studied with different surface treatments.

performance concrete. In the experiment used here, the testing time was 30 hours. Andrade et al. (2000) compared different methods for determining the diffusion coefficient in unsteady-state conditions and concluded that this procedure is the one with better reproducibility of results.

\begin{tabular}{c|c} 
Identification & Chloride diffusion Coefficient $\left(\mathrm{cm}^{2} / \mathrm{s}\right)$ \\
\hline Reference (untreated) & $3.52 \mathrm{E}-08$ \\
\hline Water repellent & $3.06 \mathrm{E}-08$ \\
\hline Acrylic & $2.75 \mathrm{E}-08$ \\
\hline Polyurethane & $1.02 \mathrm{E}-08$ \\
\hline Water repellent + Acrylic & $1.17 \mathrm{E}-08$ \\
\hline Sodium silicate & $1.99 \mathrm{E}-08$ \\
\hline
\end{tabular}

second Fick's law (non-steady-state conditions), it is possible to construct Figure 1, which relates the concrete cover with the service life in respect

$$
\frac{C_{c l}-C_{o}}{C_{s}-C_{o}}=1-\operatorname{erf}\left(\frac{e_{c l}}{2 \sqrt{D e f_{c l} t}}\right)
$$

concrete, admitted as constant (\%); $\mathrm{C}_{0}=$ initial chloride content in concrete; $\mathrm{Def}_{\mathrm{Cl}}=$ effective chloride diffusion co- to chloride attack.

In this way, equations 3 and 4, developed by the second Fick's law (Equation 2), were used. 
Considering $\mathrm{z}$ a given variable and isolating $\mathrm{e}_{\mathrm{Cl}}$, Equation 3 is obtained.

$$
z=\frac{e_{c l}}{2 \sqrt{D e f_{c l} t}} \Rightarrow e_{c l}=2 z \sqrt{D e f_{c l} t}
$$

Including $z$ in Equation 2 and isolating erf(z), Equation 4 arrives.

$$
\operatorname{erf}(z)=1-\frac{C_{c l}-C_{o}}{C_{s}-C_{o}}
$$

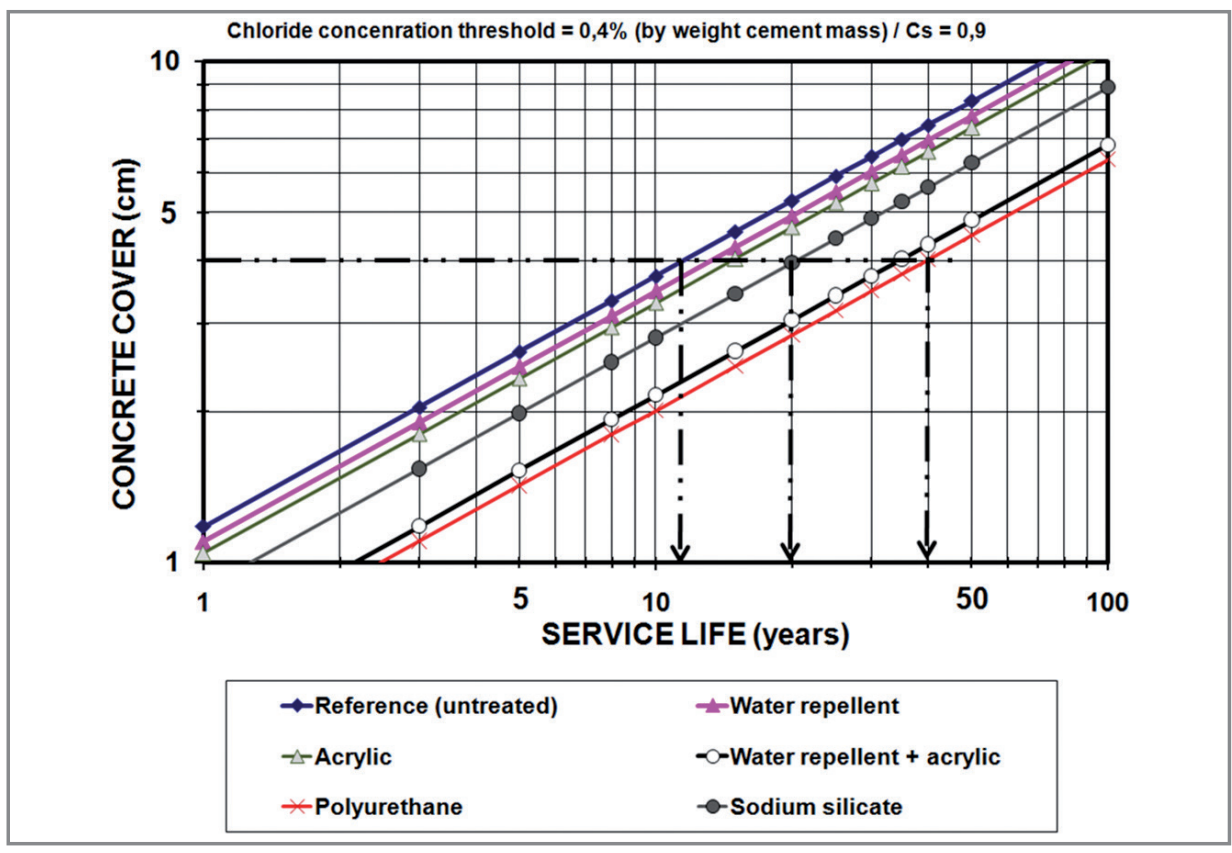

In the construction of Figure 1, $\mathrm{C}_{0}=0$ was considered because there is no chloride in the concrete at the time of molding the specimens.

Fixing a value for $\mathrm{C}_{\mathrm{S}}$ and considering $\mathrm{C}_{\mathrm{Cl}}$ equal to the critical chloride content limit for corrosion initiation in reinforcement, the Gauss error function $[\operatorname{erf}(z)]$ is found. Using tables that relate $\operatorname{erf}(z)$ with $z$, the value of $z$ is obtained. By replacing the value of $z$ and the chloride diffusion coefficient (obtained by the test) in Equation 3, an equation relating the depth at which the threshold value (for depassivation reinforcement) is reached with the time needed for the steel corrosion depassivation to be obtained. This was the reason for preparing Figure 1.

To construct this plot, a value equal to $0.9 \%$ of CS extracted from Helene (1993) was used, which specifies this reference value for concretes with compressive strength between 20 and $30 \mathrm{MPa}$, water/cement from 0.48 to 0.68 subjected to salt spray. This is the range at which the concrete substrate of this work fits.

Moreover, it should be noted that, in the present study, the term service life means the time required for the chloride content, on the surface of the reinforcement, to reach $0.4 \%$ (in respect to cement mass), which corresponds to the period called corrosion initiation. The value of $0.4 \%$ was chosen as it was the most internationally accepted as the chloride threshold for corrosion initiation, although this issue still needs to be well researched in order to reach a consensus.

It is important to highlight that the approach adopted in this paper for the solution of the second Fick's law, according to Andrade and Dal Molin (2003), is called "Error Function solution" which implies the following simplifications:

- It is assumed that the concrete material is homogeneous and isotropic;

- The only active transport mechanism is diffusion;

- It is assumed that no interactions occur between the chlorides and the components of the concrete at the time of penetration;

- The medium is considered to be infinite;

- Both the chloride diffusion coefficient and the chloride content at
Figure 1

Estimated service life (years) for untreated concrete and with the various surface protections systems of the study (diffusion coefficient by Luping; Nilsson method, 1992).

surface are constant over time;

- Chloride diffusion coefficient is completely independent of surface concentration.

It is known that there is a mistake in this methodology, since $C_{S}$ tends to increase and chloride diffusion coefficient decreases over time. $C_{S}$ increases due to the accumulation of chlorides in the concrete surface during the exposure time and the diffusion coefficient decreases due to changes in the concrete microstructure.

As indicated by the arrows in Figure 1, for a given structure with a concrete cover thickness equal to $4 \mathrm{~cm}$, the treatments resulted in increases in service life of $15 \%, 28 \%, 244 \%, 77 \%$ and $200 \%$ for water repellent, acrylic, polyurethane, sodium silicate and double system, respectively.

Figure 2 has an overview of the increase in service life (in years) as a function of the concrete cover. It is worth to note that the larger the concrete cover is, the larger the gain in years provided by the protection, i.e., the difference between the reference series and the treated concrete is more evident. 
Figure 2

Concrete cover $\mathrm{X}$ service life

for concrete treated with water repellent $-\mathrm{C}_{\mathrm{s}}=0.9 \%$ (diffusion coefficient by the Luping and Nilsson method, 1992).

Figure 3 helps to understand this fact, showing relation between the number of years of service life attained with each protection system and the designed concrete coverage or the existing concrete cover, in the case of an old reinforced concrete structure to be protected.

A very useful way to think in terms of surface protection was proposed in Medeiros and Helene (2009)

Figure 3

Concrete cover $\mathrm{X}$ increase in service life for treated and untreated concrete - $\mathrm{C}_{\mathrm{s}}=0.9 \%$ (diffusion coefficient by the

Luping and Nilsson method, 1992).

It is important to emphasize that there is a consideration that was made in this work and can be considered as a point of method failure. It is the fact that the concrete+surface protection was not considered as a two-layer system and thus has two different diffusion properties.

However, it is difficult to con-

\section{Conclusions}

The results presented here show that the effect of raising the service

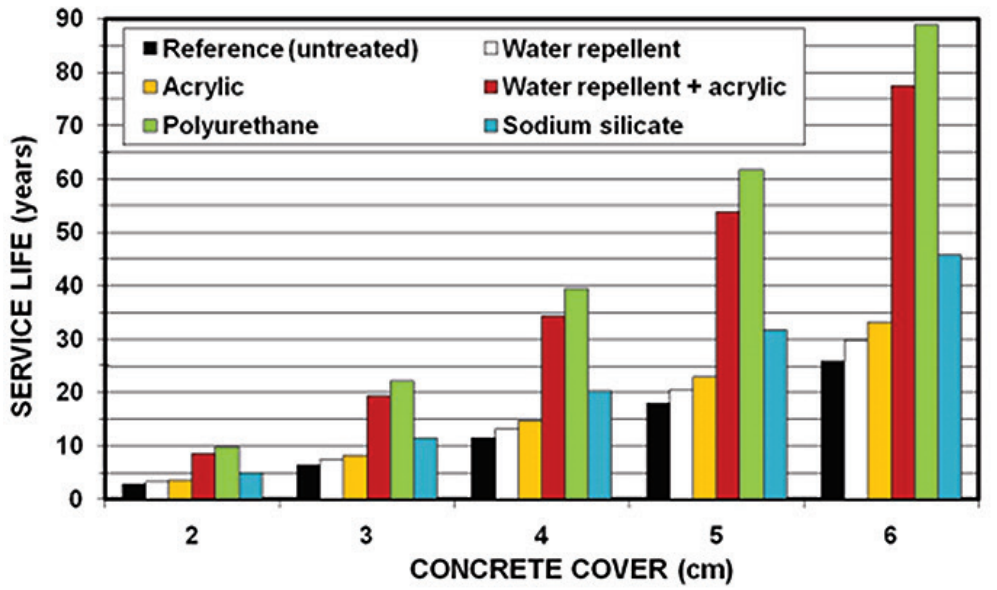

and Medeiros et al. (2012b), in which protection is converted to the equivalent concrete cover, which consists of how many inches of concrete cover thickness equal to one coat of a given protection system. The equivalent concrete covers for water repellent, acrylic, water repellent + acrylic, polyurethane and sodium silicate are $0.3 \mathrm{~cm}, 0.5 \mathrm{~cm}, 2.9 \mathrm{~cm}, 3.4$ $\mathrm{cm}$, and $1.3 \mathrm{~cm}$, respectively.

It is important to emphasize that the service life predictions presented in this work are only valid under the conditions listed below:

- The reinforced concrete structure is at the beginning of its service life (starting from the initiation period);

- The fastest degradation agent is chloride attack;

- No accidental external factors have affected the properties of the concrete cover.

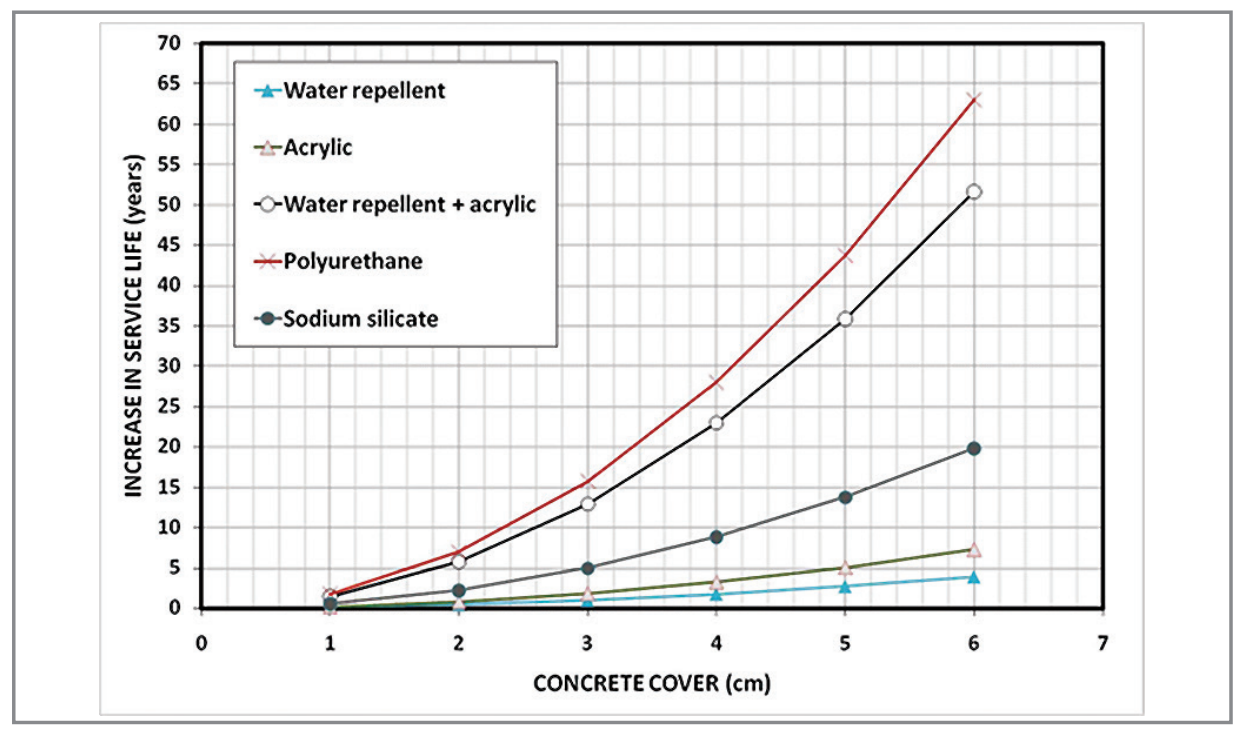

sider the thickness of each layer existing in cases where hydrophobic agents and silicates have been applied, since these treatments do not form a layer. These products penetrate the pores of the concrete and act by chemical reaction. Thus, it becomes difficult to treat the situation as two layers.

In the case of acrylic and poly- urethane would be possible to measure the layer using a meter-thick layer of paint, but it was thought better not to give different interpretation procedures for the treatments being tested in this work. For this reason, all cases in this study were considered as a single layer with a single chloride diffusion coefficient. life of a surface protection for concrete exposed to marine environment is highly influenced by the thickness of the existing concrete cover. This means 
that the thicker the concrete cover of the reinforcement is, the higher the increase of service life offered by a particular protection system will be. This information is important for professionals involved in designs of new reinforced concrete structures as well as in repairs of existing structures, helping decisionmaking in the specification of materials for surface protection.

The dissemination of this information is important, since it is almost intuitive to think that the effect of a surface treatment system depends only on itself

\section{Acknowledgements}

The authors thank the University of São Paulo (POLI-USP), the Federal University of Parana (UFPR), the Insti- and this study shows the opposite. There is an influence of the concrete cover of the existing reinforced concrete structure in the performance of the surface treatment system.

This study indicates a method for testing and analyzing reinforced concrete subjected to chloride environment based on a simple chloride migration test and the use of Fick's diffusion law. This may be an important tool for analyzing this type of material to define the specification of surface protection systems.

tute for Technological Research of São Paulo (IPT) and FAPESP (The State of São Paulo Research Foundation) for
This paper shows the high capacity for increasing service life presented by surface protection systems; they can double or even triple the structure service life. However, it is important to emphasize that this increase is inherent to a regular maintenance program and schedule. This is essential due to the fact that the durability of protection systems is extremely lower than the durability of the concrete structure, and periodical maintenance is thus required to ensure their efficiency in protecting the concrete substrate over time.

making this study possible by financially supporting it.

\section{References}

ANDRADE, C., CASTEllote, M., AlONSO, C., GONZÁlEZ, C. Non-steady-state chloride diffusion coefficients obtained from migration and natural diffusion tests - Part I: Comparison between several methods of calculation. Mater. Struct., 33, p.21-28. 2000.

ANDRADE, J. J. O., DAL MOLIN, D. C. C. Considerações quanto aos modelos empregados para a previsão da vida útil das estruturas de concreto armado: despassivação por íons cloreto. Revista Engenharia Civil, 18, p.31-44. 2003.

GUIMARÃES, A. T. C., CASTAGNO JÚNIOR, R., HELENE, P. Intensity of the attack of chloride-ions: considerations about the distance of concrete members related to the coastline. Teoria e Prática na Engenharia Civil, 3, p.73-79. 2003.

HELENE, P. Contribuição ao estudo da corrosão em armaduras de concreto armado. São Paulo: Escola Politécnica, Universidade de São Paulo, São Paulo, Brazil. 1993. (Ph.D. Thesis).

LUPING, T., NILSSON, L. Rapid determination of the chloride diffusivity in concrete by applying an electrical field. ACI Mater. J., v.89, n.1, p. 49-53. 1992.

MECK, E., SIRIVIVATNANON, V. Field indicator of chloride penetration depth. Cem. Concr. Res., v.33, n.8, p. 1113-1117. 2003.

MEDEIROS, M., HELENE, P. Durabilidade e proteção do concreto armado. Revista de Tecnologia da Construção, 151, p.50-54, 2009.

MEDEIROS, M.; HOPPE FILHO, J.; HELENE, P. Influence of slice position on chloride migration tests for concrete in marine conditions. Marine struct., v.22, n.2, p.128-141, 2009.

MEDEIROS, M., H. F., HOPPE FILHO, J., BORBA, A. Y., HELENE, P. Ensaio de migração de cloretos para concreto: influência do número de fatias extraídas. REM. Revista Escola de Minas, 65, p.475-481, 2012a.

MEDEIROS, M. H. F., CASTRO-BORGES, P., ALEIXO, D. M., QUARCIONI, V. A., MARCONDES, C. G. N., HELENE, P. Reducing water and chloride penetration through silicate treatments for concrete as a mean to control corrosion kinetics. International Journal of Electrochemical Science, v.7, n.10, p. 9682-9696. 2012b.

MEDEIROS, M. H. F., GOBBI, A., RÉUS, G. C., HELENE, P. Reinforced concrete in marine environment: effect of wetting and drying cycles, height and positioning in relation to the sea shore. Constr. Build. Mater., 44, p.452-457, 2013.

MEIRA, G. R. ANDRADE, C. PADARATZ, I. J. ALONSO, C. BORBA JÚNIOR, J. C. Chloride penetration into concrete structures in the marine atmosphere zone - relationship between deposition of chlorides on the wet candle and chlorides accumulated into concrete. Cem. Concr. Comp., v.29, n.9, p.667-676. 2007.

Received: 30 May 2014 - Accepted: 15 June 2016. 